\title{
FNAC OF BREAST LUMP WITH HISTOPATHOLOGICAL CORRELATION
}

\section{Dr. Vamshi Deepak Gudipati}

Dr. Radhika

Mucharla*

\section{Dr. Rammohan}

Peddi

\section{Dr. K.Devender} Reddy
Assistant Professor, GOVT. Medical College-Siddipet, Siddipet.

Assistant Professor, GOVT. Medical College -Siddipet, Siddipet. ${ }^{*}$ Corresponding Author

Assistant Professor, GOVT. Medical College-Siddipet, Siddipet.

\section{ABSTRACT}

Introduction - FNAC has become increasingly popular in diagnosis of palpable breast masses. As it is sensitive, specific, economical and safe for screening of breast lesions

Aims and objectives - to determine the histopathologic correlation of FNAC of breast lumps seen in department of pathology, Govt medical college, siddipet.

Methods - 2 yrs. retrospective study if breast lumps, with all patients who had FNAC, with subsequent histopathological confirmation over the period July 2018-July 2020.

A total 232 cases included in which 187 cases are subjected to excision biopsy or mastectomy

Results -2 yrs. under review (2018-2020) a total of 232 FNAC of breast lump were done. 197 (84.9\%) benign cases, 13(11.6\%) malignant cases, 8 (3.5\%) inflammatory cases were diagnosed cytologically in which $98(42.24 \%)$ cases are fibro adenoma, $27(11.6 \%)$ are malignant cases and suspicious of malignancy, $26(11.2 \%)$ of gynecomastia, 23(9.91\%) of fibrocystic disease with female predominance of $8: 1$ ratio (206:26). Age ranging from 9 yrs. -85 yrs. with mean age of $47 \mathrm{yrs} \pm 14.2 \mathrm{yrs}$.

Conclusion - we therefore concluded that FNAC is a reliable diagnostic tool of breast lump in our hospital. FNAC guides the surgeons for further plan of management.

\section{KEYWORDS : biopsy, FNAC, breast, cytodiagnosis, malignancy}

\section{INTRODUCTION}

Breast carcinomas are one of the leading causes of cancer in women in developed countries. FNAC is one of the important component of triple assessment (1) along with clinical examination and mammography, which has been widely acceptable for pre-operative diagnosis of breast lesions. It is cheap, fast and reliable diagnostic method. It also reduces the frequency of open biopsy (2) from our findings we determine the correlation between the results of FNAC of breast and corresponding tissue biopsy and consequently determine the accuracy of our FNAC reporting.

\section{MATERIALS AND METHODS}

This is a retrospective study conducted in department of pathology, GOVT. medical college, siddipet. between July 2018 - July 2020. All patients who had FNAC of breast lumps with subsequent histopathological confirmation over the period were included in the study. FNA were done by pathologist using $5 \mathrm{ml}-10 \mathrm{ml}$ syringe with $23 \mathrm{G}$ needle, smears were stained with haematoxylin and eosin (H\&E), Leishman and papanicolaou stain. (3)

FNAC followed by excision biopsy / lumpectomy or mastectomy were included in study.

\section{RESULTS}

Out of 232 cases $84.9 \%$ (197) benign cases, $11.6 \%$ (27) cases malignant, $3.5 \%$ (8) inflammatory cases were diagnosed cytologically in which $98((42.24 \%)$ cases of fibroadenoma, $27(11.6 \%)$ of malignant and suspicious of malignancy, $26(11.2 \%)$ of gynecomastia, $23(9.9 \%)$ of fibrocystic disease with female predominance of 8:1 ratio(206:26), range from age group 9 years - 85 years with mean age of $47+\ldots 14.2$ years.

Majority of benign cases 197(84.99\%) belongs to 30-45 yrs. age group. Majority of malignant cases 27 (11.6\%) belongs to 50-65 yrs. age group. Out of 232 cases 187 case are came to histopathological examination, $6(3.20 \%)$ cases were inconsistent with cytological diagnosis.(Table 1)

\begin{tabular}{|l|l|l|lc|l|}
\hline $\begin{array}{l}\text { CYTODIAGNO } \\
\text { SIS }\end{array}$ & $\begin{array}{l}\text { No of } \\
\text { cases }\end{array}$ & $\begin{array}{l}\text { Tissue } \\
\text { available }\end{array}$ & $\begin{array}{l}\text { HISTOPATHOL } \\
\text { OGY }\end{array}$ & $\begin{array}{l}\text { Inconsistent } \\
\text { diagnosis }\end{array}$ \\
\hline & & & \multicolumn{2}{l}{$\begin{array}{l}\text { Consistent } \\
\text { inconsistent }\end{array}$} & \\
\hline Firoadenoma & 98 & 98 & 97 & 01 & Phyllodes \\
\hline Gynecomastia & 26 & 26 & 26 & - & - \\
\hline $\begin{array}{l}\text { Fibrocystic } \\
\text { disease }\end{array}$ & 23 & 11 & 11 & - & - \\
\hline $\begin{array}{l}\text { Giant } \\
\text { fibroadenoma }\end{array}$ & 07 & 07 & 07 & - & - \\
\hline Fibroadenosis & 10 & 05 & 05 & - & - \\
\hline Phyllodes & 05 & 05 & 05 & - & - \\
\hline $\begin{array}{l}\text { Epithelial } \\
\text { hyperplasia }\end{array}$ & 05 & 04 & 03 & & IDC \\
\hline ADH & 06 & 06 & 04 & 02 & IDC (2) \\
\hline $\begin{array}{l}\text { Suspicious for } \\
\text { malignancy }\end{array}$ & 08 & 08 & 06 & 02 & IDC (2) \\
\hline Malignancy & 13 & 13 & 13 & - & - \\
\hline TOTAL & 232 & 187 & 181 & 06 & - \\
\hline
\end{tabular}

Table no 1: correlation of FNAC and histopathology in Breast lumps

IDC - Infiltrating duct cell carcinoma, ADH - Atypical ductal hyperplasia 


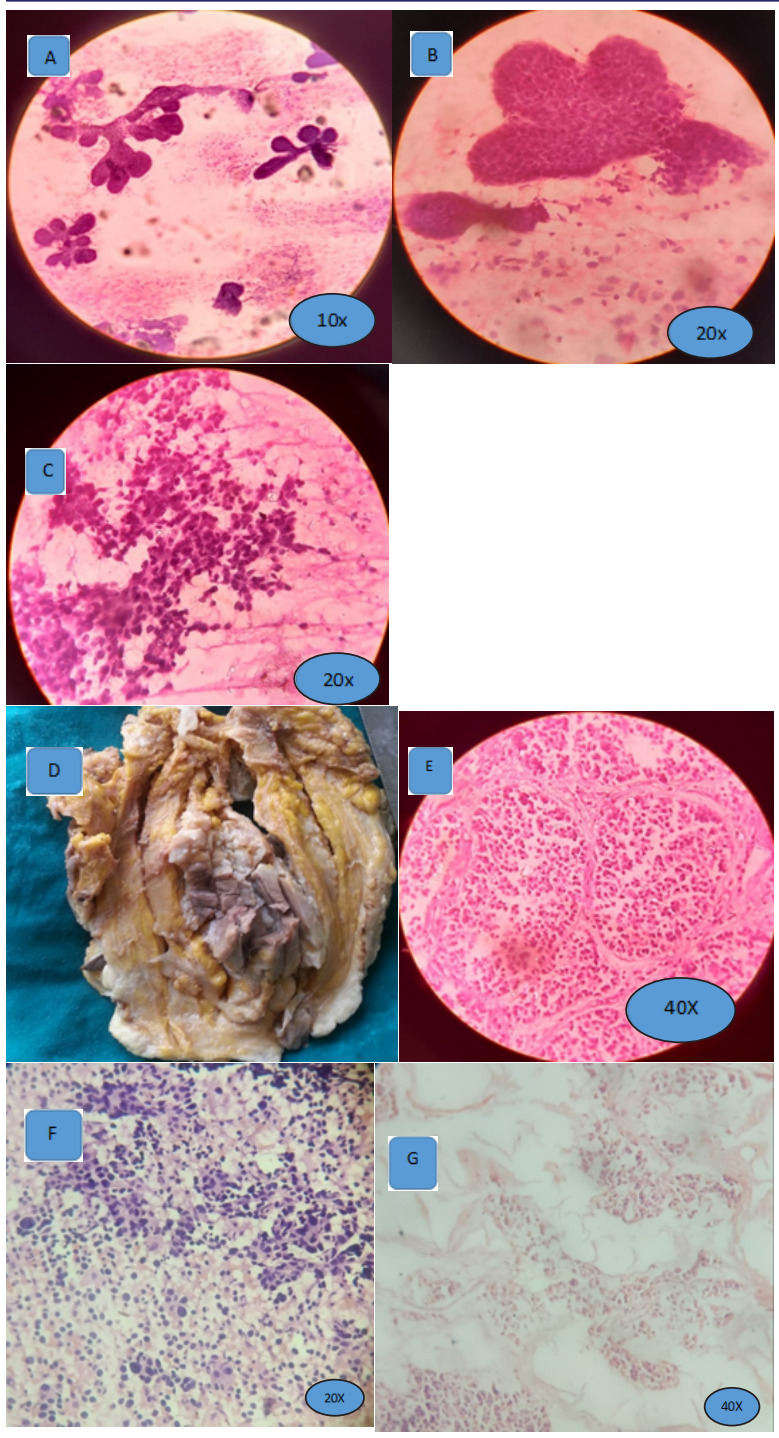

Figure A\&B - Benign Phyllodes tumour FNAC H\&E stain

Figure C, D \&E - Infiltrating Ductal Carcinoma both FNAC and Histopathology pictures H\&E stain

Figure F-Medullary carcinoma of breast FNAC H\&E stain

Figure $\mathrm{G}-$ Mucinous carcinoma of breast Histopathology H\&E

\section{DISCUSSION}

FNAC as a part of triple assessment for breast lumps is an accepted and established method for determining the nature of breast lumps with a high grade of accuracy. $(4,5)$ FNA procedure is a safe method and minimize the unnecessary surgical procedures.

The ideal method of biopsy to diagnose breast cancer is debatable and should depend on the expertise available in the unit, as well as the physical characteristics of the lump. FNAC is a reliable and relevant method for the pathological diagnosis of breast carcinomas in a developing nation like India. If the initial FNAC is inadequate, CNB can be a useful second line method of diagnosis. Excision biopsy should be the last option to obtain a pathological diagnosis. (10)

In our study, out of 232 cytologically diagnosed cases, 187 cases were confirmed histopathologically. There were 13 malignant cases in FNAC like medullary carcinoma of breast, mucinous carcinoma of breast and infiltrative ductal carcinoma of breast, which were correlated by Histopathology also. Out of 187 cases 6 cases were inconsistent with cytological diagnosis, in which 5 were as Infiltrating duct cell carcinoma (Fig C\&D) and remaining 1 as benign phyllodes
(Fig A\&B) This might be due to inadequate sampling, it is better to re-aspirate the lesion and to correlate the FNAC findings with clinical diagnosis and mammograms and to go for biopsies whenever they are needed, to avoid misdiagnosis. The false negative rate varies from $1-8 \%$ in different studies (6-9)

The diagnostic accuracy is close to $99 \%$ in benign and $84 \%$ in malignant cases. In our study, 99.46\% cytohistopathological correlation was observed for benign and malignant lesions. Hang Qin et al., (6), Mohammad et al., (7), Tiwari M (8) had also observed near the same results in their studies.

In the present study, 2 cases which were cytologically diagnosed as lesions "suspicious for malignancy" were confirmed as malignant lesions on doing histopathological studies.

In the study, sensitivity and specificity of breast FNAC were $96.9 \%$ and $98.7 \%$ respectively. Diagnostic accuracy in our study was reported to be $99.46 \%$. Accuracy rates of $84-99.5 \%$ have been reported in various series (11)

\section{CONCLUSION}

FNAC is a reliable fast and accurate diagnostic method for assessment of breast lumps. It has few manageable complications and can be done on outpatient basis.

Therefore correlation between clinical examination, FNAC, and histopathology holds high significance in the diagnosis of breast cancer.

\section{REFERENCES}

1. Kocjan G, Bourgain C, Fassina A, et al. the role of breast FNAC in diagnosis and clinical management: a survey of current practice. Cytopathology.2008; 19:271-78.[PubMed] [Google Scholar]

2. Hindle WH, payne PA, Pan EY. The use of fine needle aspiration in the evaluation of persistent palpable dominant breast masses. Am J Obstetrics Gynaecol. 1993; 18(6 part1):181-18. [PubMed][Google Scholar]

3. Obasei DE, Olu-Edo AN, Ogunbiyi JO. Diagnostic accuracy of fine needle aspiration cytology of palpable breast masses in Benin City, Nigeria. West af J Med. 2010; 29(4):259-262. PubMed. [PubMed] [Google Scholar]

4. Purasiri P, AbdallaM,Heys SD, Ah see AK, Mc ean ME, Gilbert FJ, et al. A novel diagnostic index for use in the breast clinic. JR coll surg edinb. 196; 1:30-3. [PubMed][Google Scholar]

5. Aufman , Shpitx B,ShapiroM, Rona R, Lew S, Dinbar A. Triple approach in diagnosis of dominant breast masses: combined physical examination, mammography and fine needle aspiration. J Surg Oncol. 199; 56:25-57. [PubMed][Google Scholar]

6. Zhang Qin, Nie Shigui, Chen Yuhua, Zhou Limei. Fine needle aspiration cytology of breast lesions: Analysis of 323 cases. The Chinese-german ournal of clinical oncology. 200; 3(3):172-7. [Google Scholar]

7. Mohammad AZ, Edino ST, Ochicha O, Alhassan SU. Value of fine needle aspiration biopsy preoparatie diagnosis of palpable breast lumps in resource-0poor countries:a Nigerian experience. Annals of African medicine. $2005 ;(): 11-22$. [Google Scholar]

8. Tiwari M. Role of FNAC in diagnosis of breast lumps. Kathmandu university medical journal. 2007; 5:25-17. [PubMed][Google Scholar]

9 O'Neil S, Castelli M, Gattuso Plusens L, Madsen. Aranha G. Fine neddle aspiration of 697 palpable breast lesions with histopathological correlation. Surgery. 1997; 122(4):82-28. [PubMed] [Google Scholar]

10. Daid E ibiunle, John A Omotayo, Olufemi O Ariyibi.Fine needle aspiration cytology of breast lumps with histopathological correlation in owo, ondo state, Nigeria: a five year review.

11. Wilison EJ, Schuetteke CM,Ferrier CM, Franzini DA. Fine needle aspiration of breast masses. An analysis of 276 aspirates. Acta Cytol. 1989; 33:613-19. [PubMed][Google Scholar] 